\title{
Microwave-Assisted One Pot Three-Component Synthesis of Novel Bioactive Thiazolyl-Pyridazinediones as Potential Antimicrobial Agents against Antibiotic-Resistant Bacteria
}

\author{
Sraa Abu-Melha ${ }^{1}$, Sobhi M. Gomha ${ }^{2,3, *(\mathbb{D}, \text { Amr S. Abouzied }}{ }^{4,5}{ }^{(}$, , Mastoura M. Edrees ${ }^{1,5}{ }^{(}$, \\ Ahmed S. Abo Dena ${ }^{5,6}$ and Zeinab A. Muhammad ${ }^{5}$ \\ 1 Department of Chemistry, Faculty of Science, King Khalid University, Abha 61413, Saudi Arabia; \\ sabomlba@kku.edu.sa (S.A.-M.); mstorh@kku.edu.sa (M.M.E.) \\ 2 Chemistry Department, Faculty of Science, Cairo University, Giza 12613, Egypt \\ 3 Chemistry Department, Faculty of Science, Islamic University in Almadinah Almonawara, \\ Medina 42351, Saudi Arabia \\ 4 Pharmaceutical Chemistry Department, College of Pharmacy, University of Hail, Hail 81442, Saudi Arabia; \\ amrabou.zied@yahoo.com \\ 5 Pharmaceutical Chemistry Department, National Organization for Drug Control and Research (NODCAR), \\ Giza 12311, Egypt; ahmed_said5899@yahoo.com (A.S.A.D.); zeinab.a.muhammad@gmail.com (Z.A.M.) \\ 6 Faculty of Oral and Dental Medicine, Future University in Egypt (FUE), New Cairo 11835, Egypt \\ * Correspondence: s.m.gomha@gmail.com or smgomha@iu.edu.sa; Tel.: +20-237-400-304
}

\section{check for}

updates

Citation: Abu-Melha, S.; Gomha, S.M.; Abouzied, A.S.; Edrees, M.M.; Abo Dena, A.S.; Muhammad, Z.A. Microwave-Assisted One Pot

Three-Component Synthesis of Novel Bioactive Thiazolyl-Pyridazinediones as Potential Antimicrobial Agents against Antibiotic-Resistant Bacteria. Molecules 2021, 26, 0 .

https://doi.org/

Academic Editor: Luana Bagnoli

Received: 23 May 2021

Accepted: 5 July 2021

Published: 12 July 2021

Publisher's Note: MDPI stays neutral with regard to jurisdictional claims in published maps and institutional affiliations.

Copyright: (c) 2021 by the authors. Licensee MDPI, Basel, Switzerland. This article is an open access article distributed under the terms and conditions of the Creative Commons Attribution (CC BY) license (https:/ / creativecommons.org/licenses/by/ $4.0 /)$
Abstract: Pyridazine and thiazole derivatives have various biological activities such as antimicrobial analgesic, anticancer, anticonvulsant, antitubercular and other anticipated biological properties. Chitosan can be used as heterogeneous phase transfer basic biocatalyst in heterocyclic syntheses. Novel 1-thiazolyl-pyridazinedione derivatives were prepared via multicomponent synthesis under microwave irradiation as ecofriendly energy source and using the eco-friendly naturally occurring chitosan basic catalyst with high/efficient yields and short reaction time. All the prepared compounds were fully characterized by spectroscopic methods, and their in vitro biological activities were investigated. The obtained results were compared with those of standard antibacterial/antifungal agents. DFT calculations and molecular docking studies were used to investigate the electronic properties and molecular interactions with specific microbial receptors.

Keywords: thiazolyl-pyridazinedione; hydrazonoyl chlorides; microwave irradiation; antibioticresistant bacteria; molecular docking

\section{Introduction}

In recent years, a substantial number of pyridazine derivatives containing different moieties and/or substituents have demonstrated anti-inflammatory/analgesic, antipyretics, antiplatelet, anticancer, antidiabetic, antihypertensive, antidepressant/anxiolytic, anticonvulsant, antifungal, antibacterial, antitubercular, anti-bronchial asthma, antiallergic and other anticipated biological properties [1-8]. Moreover, thiazoles are considered an important class of heterocyclic compounds, found in many potent biologically active molecules such as sulfathiazole (an antimicrobial drug), Ritonavir (an antiretroviral drug), Abafungin (an antifungal drug) and Tiazofurin (an antineoplastic drug).

Continuously over the years, it has been noticed that interesting biological activities $[9,10]$ were associated with thiazole derivatives. Recently, thiazoles have had a wide range of applications in drug development for the treatment of allergies, inflammation, schizophrenia, bacterial diseases, hypnotics and more recently for the treatment of pain, as fibrinogen receptor antagonists with antithrombotic activity and as new inhibitors of bacterial DNA gyrase B [11-16].

Multi-component reactions (MCRs) are one-pot processes with at least three components to form a single product, which incorporates most or even all of the starting 
materials [17-20]. The huge interest in such MCRs during the last years has been oriented towards developing combinatorial chemistry procedures, because of their high efficiency and convenience in comparison to multistage procedures. Additionally, the utility of MCRs under microwave irradiation (MWI) in the synthesis of heterocyclic compounds enhanced reaction rates and improved regioselectivity [21-24].

Chitosan, a biocompatible and biodegradable naturally occurring polysaccharide, is a copolymer containing both glucosamine and $\mathrm{N}$-acetylglucosamine units. It can be used as a heterogeneous phase transfer basic biocatalyst in heterocyclic syntheses, such as enantioselective syntheses of asymmetric products with chiral center(s) $[25,26]$, Michael addition reactions [27-29], as well as transition metal support for the preparation of heterogeneous catalysts [30]. The presence of amino groups is responsible for the basic nature of chitosan. Keeping this in mind, in continuation of our previously reported works on the synthesis of new biologically active agents [31-37], we present herein an efficient synthesis of novel 1-thiazolyl-pyridazinedione derivatives as antimicrobial agents, which have not been reported hitherto in a multicomponent synthesis under MWI as an ecofriendly energy source and using the eco-friendly naturally occurring chitosan catalyst.

\section{Results and Discussion}

\subsection{Synthesis}

In continuation of our previous work to synthesize bioactive heterocyclic compounds under mild conditions [38-43], we wish to report herein mild and efficient procedures for the synthesis of some novel 1-thiazolyl-pyridazinedione derivatives via the threecomponent reaction of maleic anhydride $\mathbf{1}$, thiosemicarbazide 2 and the appropriate 2-oxo$\mathrm{N}$-arylpropanehydrazonoyl chlorides $\mathbf{3 a}-\mathbf{f}$ in ethanol in the presence of chitosan under MWI at $500 \mathrm{~W}$ and $150{ }^{\circ} \mathrm{C}$ for $4-8 \mathrm{~min}$. as monitored by TLC (Scheme 1 ).

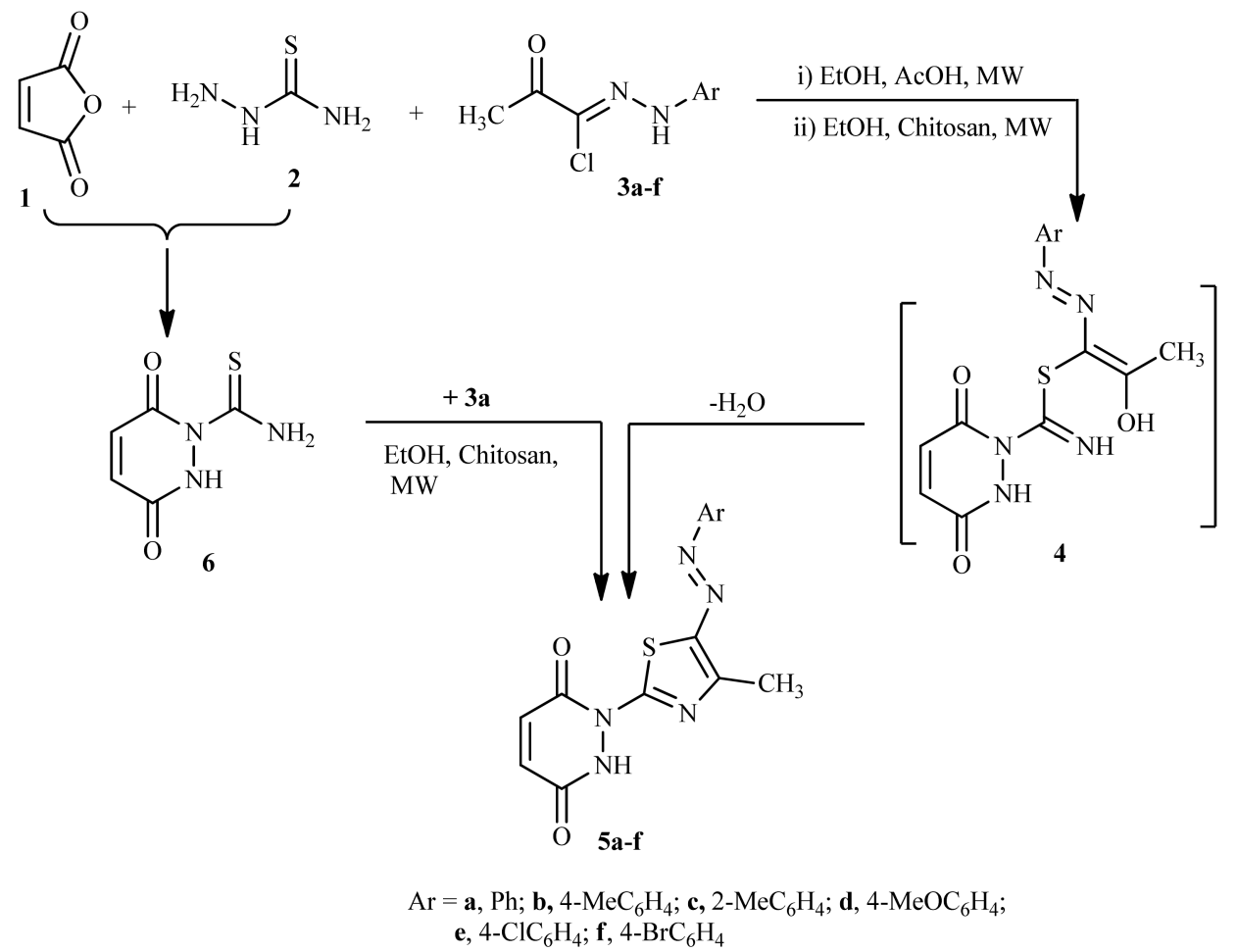

Scheme 1. Synthesis of arylazothiazole derivatives $\mathbf{5 a - f}$.

The structure of $\mathbf{5 a}-\mathbf{f}$ was confirmed by their spectral data (IR, MS and ${ }^{1} \mathrm{H}-\mathrm{NMR}$ ), elemental analyses and alternative synthetic routes. For example, the ${ }^{1} \mathrm{H}$ NMR spectra of compounds 5a-f exhibited singlet signals at $\delta \sim 2.56 \mathrm{ppm}\left(\mathrm{CH}_{3}\right)$ and one $\mathrm{D}_{2} \mathrm{O}$ exchangeable peaks at $\delta \sim 10.71 \mathrm{ppm}$ corresponding to $\mathrm{NH}$-phenyl, in addition to the expected signals for 
the aromatic protons and the two doublet signals of the $\mathrm{CH}=\mathrm{CH}$ protons. The IR spectra of product 6 revealed in each case three absorption bands in the regions $v \sim 1654,1668$ and $3435 \mathrm{~cm}^{-1}$ due to the two carbonyl groups and NH group. The mass spectra of products 5a-f revealed a molecular ion peak for each one, which is consistent with their respective molecular weights.

In the light of the foregoing results, the mechanism outlined in (Scheme 1) seems to be the most plausible pathway for the formation of compounds $5 \mathbf{a}-\mathbf{f}$ from the reaction of the $1+2+3$. The reaction involves initial formation of thiohydrazonate intermediate 4 via $S$-alkylation, with removal of $\mathrm{HCl}$, which underwent dehydrative cyclization to afford the final product 5 .

Compound $\mathbf{5 a}$ was alternatively synthesized by reacting carbothioamide $\mathbf{6}$ (prepared separately via condensation of maleic anhydride $\mathbf{1}$ and thiosemicarbazide 2) with 2-oxo-Nphenylpropanehydrazonoyl chloride (3a) in ethanol containing catalytic amount of chitosan under MWI (Scheme 1). The obtained product was found to be identical with 5a in all respects (TLC, mp. and IR spectrum), which affords further evidence to all structures 5a-f.

In an identical way, when the three-component reaction of maleic anhydride $\mathbf{1}$, thiosemicarbazide $\mathbf{2}$ and the appropriate ethyl ( $N$-arylhydrazono)-chloroacetates 7a-e under the same reaction condition, it yielded in each case a single product, namely, 1-(4oxo-5-(2-arylhydrazono)-4,5-dihydrothiazol-2-yl)-1,2-dihydropyridazine-3,6-diones 9a-e (Scheme 2).

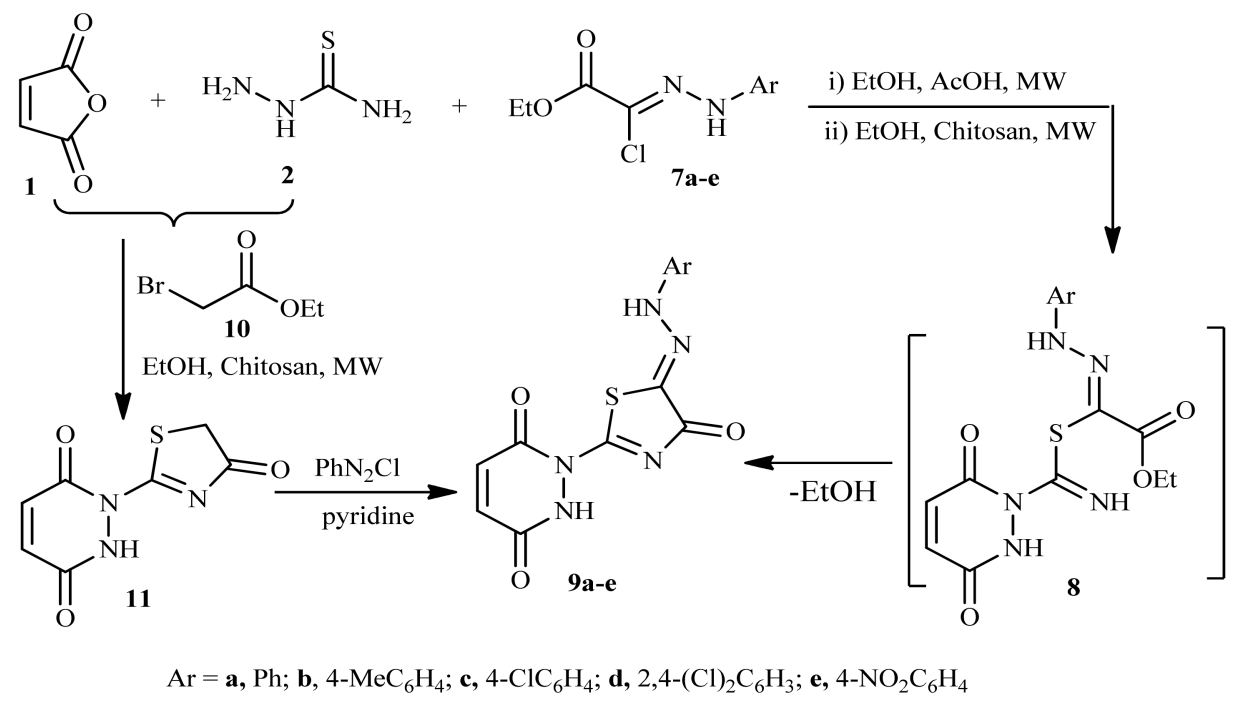

Scheme 2. Synthesis of arylhydrazothiazolone derivatives 9a-e.

The structure of compounds 9a-e was proved based on spectral data, elemental analyses and chemical transformations. The spectroscopic information confirmed the reaction product 9 via intermediate 8 with elimination of $\mathrm{EtOH}$ molecule (Scheme 2).

Coupling of thiazolone $\mathbf{1 1}$ (prepared separately from reaction of carbothioamide derivative 6 with ethyl bromoacetate 10 in ethanol/chitosan under reflux) with $\mathrm{PhN}_{2} \mathrm{Cl}$ in pyridine yielded a product was found to be identical to 9a in all regards (mp., TLC and IR spectrum), providing an additional evidence to all 9a-e structures.

From literature reports [44-47] we found that compounds bearing more than one thiazole ring unit also exhibit good biological activities. For example, Myxothiazol is an inhibitor of the mitochondrial cytochrome bc1 complex and Bleomycin is an anticancer agent, containing $2,4^{\prime}$-bis thiazole system. From the above findings, we thought it is useful to synthesize a heterocyclic ring system carrying bis-thiazole moiety associated with pyridazine ring. This aim was achieved via the reaction of bis-hydrazonoyl chlorides 12a and $\mathbf{1 2 b}$ with two moles of maleimide $\mathbf{1}$ and two moles of thiosemicarbazide 2 under MWI in presence of chitosan to afford the respective bis-thiazoles 13 and $\mathbf{1 4}$ in a good yield 
(Scheme 3). The structure of compounds 13 and 14 was proven based on spectral data and elemental analyses (Experimental part).

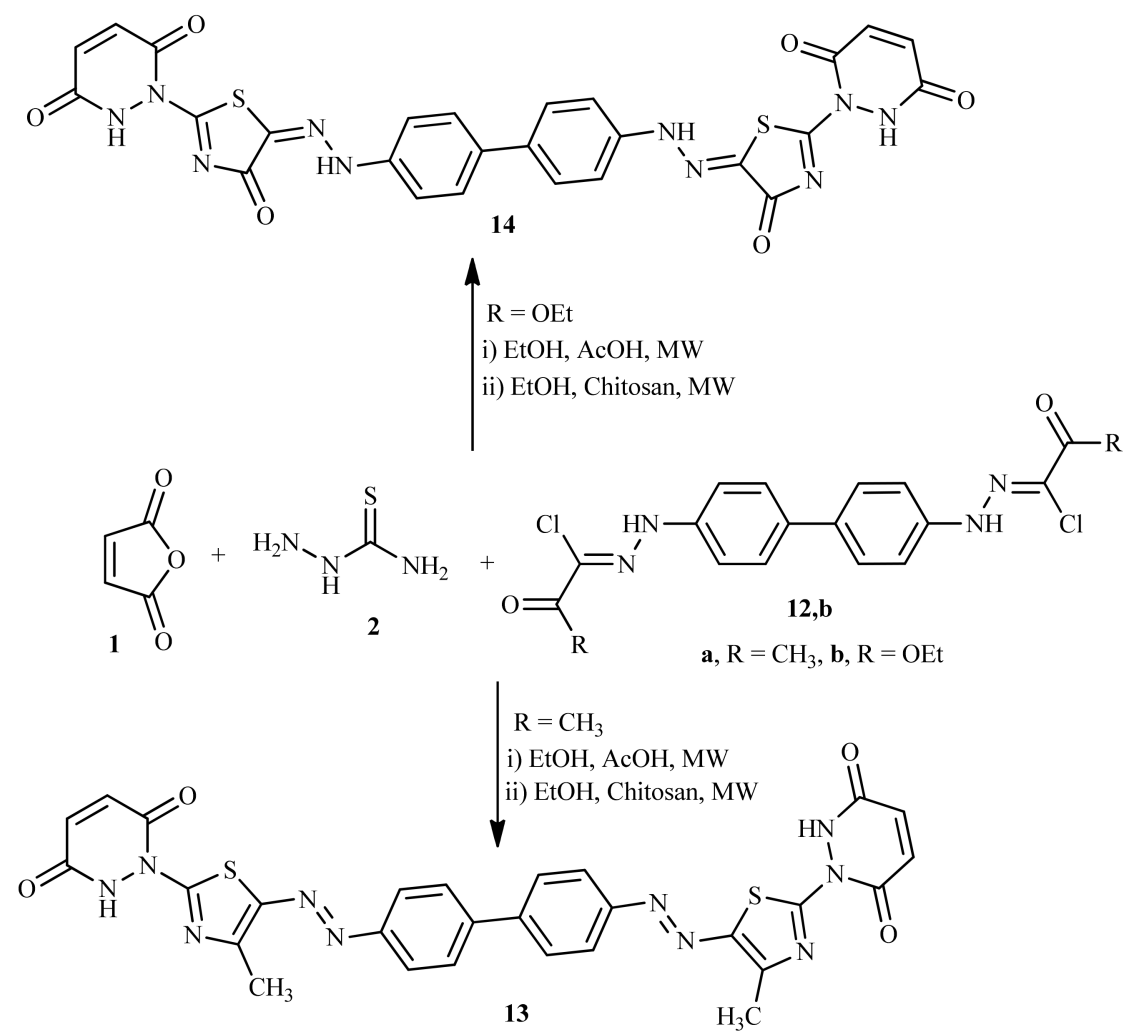

Scheme 3. Synthesis of bis-thiazole derivatives 13 and 14.

\subsection{XTT Assay Results}

The minimum inhibitory concentration (MIC) of the tested compounds on cell metabolism/viability of $S$. aureus, $P$. aeruginosa and C. albicans was determined using XTT assay compared to the standard counterparts (vancomycin and amphotericin B).

The results presented in Table 1 depict that most of the investigated compounds have higher activities towards bacterial strains than fungal ones. Compound $9 d$ has a low MIC and acts against all resistant bacterial (P. aeruginosa and S. aureus, MIC: 0.42 and $1.84 \mathrm{~g} / \mathrm{mL}$, respectively) and fungal (Candida albicans, MIC: $2.17 \mathrm{~g} / \mathrm{mL}$ ) strains, indicating that it has a significant antibacterial and antifungal activity. Compounds 5a, 5b, 5c, 5e, 5f, 9b, 9c, and 13, on the other hand, show no effect on the azole-resistant C. albicans ATCC10231 fungus. The majority of the studied molecules demonstrate different degrees of activity towards the resistant S. aureus (MRSA) TCC-BAA-1720. Compounds 5d, 9b, and 14 appeared to be the most effective. Compound $\mathbf{5 d}$ was more effective than the reference drug vancomycin against the sensitive Pseudomonas aeruginosa ATCC 10145 and resistant Pseudomonas aeruginosa ATCC BAA-2108. Compounds 5c, 5d, 9b, 9c and 13 showed no activity against the resistant Pseudomonas aeruginosa ATCC BAA-2108. In addition, compound 14 shows a good antimicrobial activity against $S$. aureus and $P$. aeruginosa (MIC: 1.13 and $1.49 \mu \mathrm{g} / \mathrm{mL}$, respectively). In order to correlate the in silico results with those of the experimental antibacterial testing, SAP and FabI receptors were chosen for docking with the tested compounds. 
Table 1. MIC of the synthesized compounds against sensitive and resistant microorganisms.

\begin{tabular}{|c|c|c|c|c|c|c|}
\hline \multirow[b]{3}{*}{ Sample } & \multicolumn{6}{|c|}{ Minimum Inhibitory Concentration $(\mu \mathrm{g} / \mathrm{mL})$} \\
\hline & \multicolumn{2}{|c|}{ Gram Positive Bacteria } & \multicolumn{2}{|c|}{ Gram Negative Bacteria } & \multicolumn{2}{|c|}{ Fungus } \\
\hline & $\begin{array}{c}\text { Sensitive } \\
\text { Staphylococcus } \\
\text { aureus ATCC } \\
25923\end{array}$ & $\begin{array}{c}\text { Methicillin- } \\
\text { Resistant } \\
\text { Staphylococcus } \\
\text { aureus (MRSA) } \\
\text { ATCC-BAA-1720 }\end{array}$ & $\begin{array}{c}\text { Sensitive } \\
\text { Pseudomonas } \\
\text { aeruginosa } \\
\text { ATCC10145 }\end{array}$ & $\begin{array}{l}\text { Penicillins and } \\
\text { Cephalosporins- } \\
\text { Resistant } \\
\text { Pseudomonas } \\
\text { aeruginosa } \\
\text { ATCC BAA-2108 }\end{array}$ & $\begin{array}{c}\text { Azole-Sensitive } \\
\text { Candida } \\
\text { albicans ATCC } \\
\mathbf{1 8 8 0 4}\end{array}$ & $\begin{array}{c}\text { Azole-Resistant } \\
\text { Candida } \\
\text { albicans ATCC } \\
10231\end{array}$ \\
\hline $5 a$ & 1.91 & 3.82 & 18.23 & 1.55 & $\mathrm{NA}^{\mathrm{a}}$ & NA \\
\hline $5 b$ & 3.37 & 1.85 & 3.92 & 14.29 & 2.61 & NA \\
\hline $5 c$ & 7.81 & 5.74 & NA & NA & 62.5 & NA \\
\hline $5 d$ & 0.15 & 0.49 & NA & NA & 0.29 & 19.07 \\
\hline $5 e$ & 1.82 & 2.91 & 5.07 & 62.5 & 25.48 & NA \\
\hline $5 f$ & 31.25 & 15.13 & 3.04 & 1.79 & 22.93 & NA \\
\hline $9 a$ & 1.90 & 5.30 & 3.97 & 14.81 & 3.93 & 13.91 \\
\hline $9 b$ & 5.29 & 1.27 & 10.13 & NA & 11.53 & NA \\
\hline $9 c$ & 0.43 & 3.13 & NA & NA & NA & NA \\
\hline $9 d$ & 0.71 & 0.42 & 0.93 & 1.84 & 0.65 & 2.17 \\
\hline $9 e$ & 0.48 & 9.19 & 0.93 & 3.91 & 4.49 & 15.04 \\
\hline 13 & 9.04 & 7.29 & NA & NA & 250 & NA \\
\hline 14 & 0.49 & 1.13 & NA & 1.49 & 0.18 & 3.18 \\
\hline Vancomycin & 0.24 & 0.98 & 0.49 & 3.9 & ND & ND \\
\hline Amphotericin $\mathrm{B}^{\mathrm{b}}$ & ND & ND & ND & ND & 0.24 & 1.95 \\
\hline
\end{tabular}

${ }^{a} \mathrm{NA}$, not active ${ }^{\mathrm{b}} \mathrm{ND}$, not determined.

\subsection{Molecular Modeling}

At the B3LYP/6-311G level of theory, the geometries of the synthesized molecules that demonstrated the greatest biological activity in the XTT experiments (5d, 5e, 9c, and 9d) were investigated (Figure 1). The findings revealed that the molecules under investigation are nearly planar. The highest occupied molecular orbitals (HOMO) are noticed on the substituted phenyl and thiazole rings in all of the investigated compounds, whereas the lowest unoccupied molecular orbitals (LUMO) are found on the pyridazine-3,6-dione rings. Molecular orbital analysis can give information about the reactivity and excitability of the studied molecules. From HOMO/LUMO analysis, it can be concluded that molecules with narrow energy gaps (e.g., $5 \mathrm{~d}$ and $9 \mathrm{c}$ ) may show better reactivity/excitability than those having wide energy gaps (e.g., 5e and $\mathbf{9 d}$ ).

The quantum mechanical descriptors of the picked molecules are summarized in Table 2. The energy gaps between HOMO and LUMO were discovered to be in the range of 2.87 to $3.06 \mathrm{eV}$, with $\mathbf{5 d}$ having the smallest energy gap.

Molecular docking was used to study the ligand-receptor interactions that may result in the obtained biological activities of the studied molecules. Thiazole derivatives have been reported to exhibit strong antibacterial activity against Staphylococcus aureus and Candida albicans. As a result, the studied candidate chemicals have strong antibacterial activity against these two pathogens. Furthermore, antibacterial activity against Pseudomonas aeruginosa was established by the substances under investigation. Accordingly, we chose the most appropriate receptors from the organisms mentioned above for molecular docking investigations.

During disseminated/mucosal infections of Candida albicans, secreted aspartic proteinase (SAP) plays a key function as a virulence factor. This receptor is assumed to be involved in the fungus' attachment and invasion, and so plays a role in its pathogenicity. As a result, SAPs may be useful as pharmacological target receptors for candidiasis treatment [48].

Staphylococcus aureus is a common Gram-positive bacterium that can cause wound infections and staphylococcal scalded skin syndrome (a cutaneous reaction to a staphylococcal exotoxin absorbed into the circulation) [49]. One of the essential components of the FAS II system (a group of fatty acid synthases used by most of bacteria and plants to catalyze fatty acid synthesis) is enoyl-[acyl-carrier-protein] reductase (FabI). Other bacteria, 
such as Pseudomonas aeruginosa, require this enzyme as well. In order to correlate the in silico results with those obtained from the experimental antibacterial tests, SAP and FabI were chosen for docking with the compounds of interest.
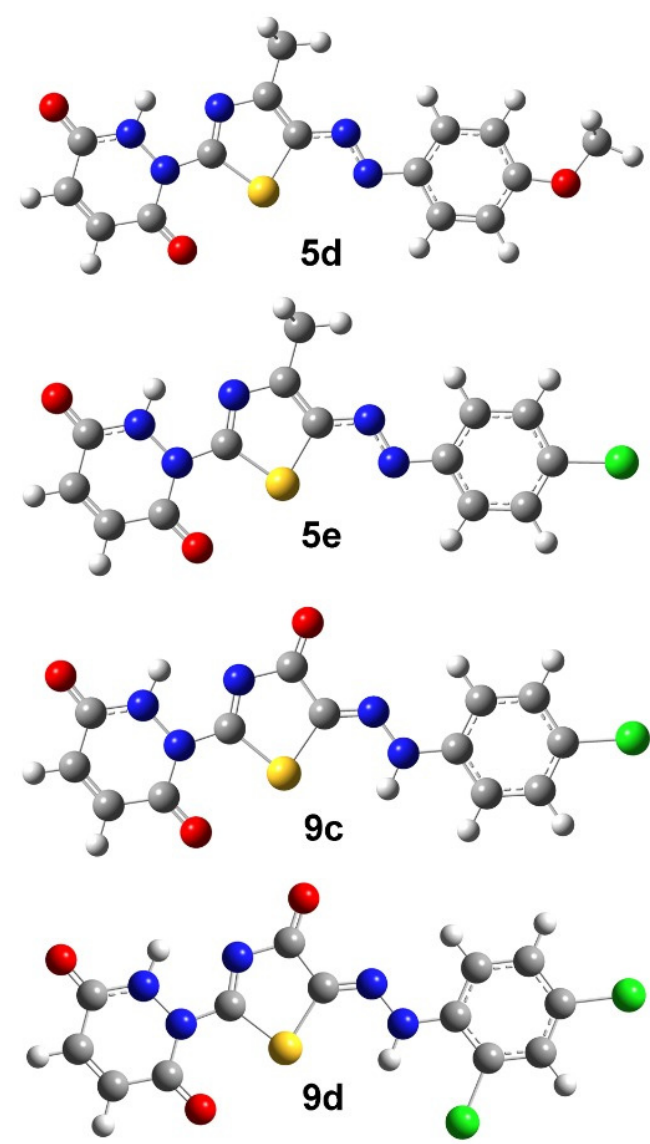

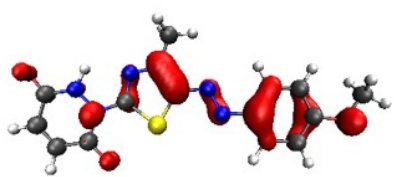

5d HOMO

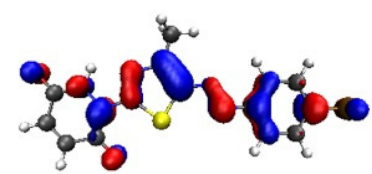

5e HOMO

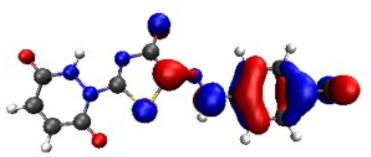

9c HOMO

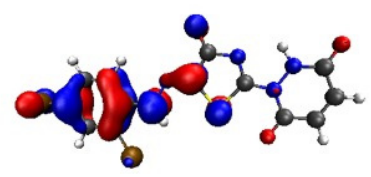

9d HOMO

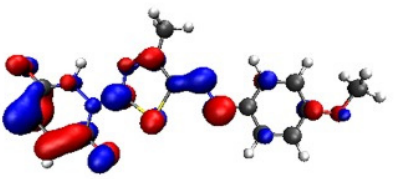

5d LUMO

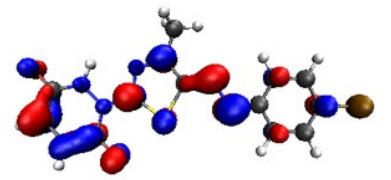

5e LUMO

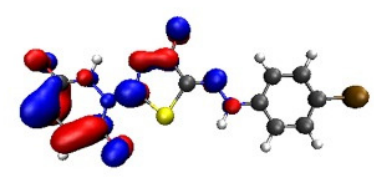

9c LUMO

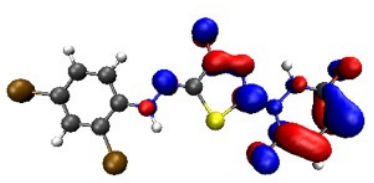

9d LUMO

Figure 1. Optimized molecular geometries and molecular orbitals of candidate molecules with the highest antimicrobial properties.

Table 2. Quantum chemical parameters of compounds 6d, 6e, 10c and 10d.

\begin{tabular}{ccccc}
\hline Parameter & $\mathbf{5 d}$ & $\mathbf{5 e}$ & $\mathbf{9 c}$ & $\mathbf{9 d}$ \\
\hline $\mathrm{E}_{\mathrm{t}}(\mathrm{eV})$ & -40.188 & -49.578 & -50.556 & -63.062 \\
$\mathrm{E}_{\mathrm{LUMO}}(\mathrm{eV})$ & -3.13 & -3.43 & -3.65 & -3.72 \\
$\mathrm{E}_{\mathrm{HOMO}}(\mathrm{eV})$ & -6.01 & -6.47 & -6.58 & -6.77 \\
$\Delta \mathrm{E}(\mathrm{eV})$ & 2.87 & 3.03 & 2.93 & 3.06 \\
Ionization energy $(\mathrm{eV})$ & 6.01 & 6.47 & 6.58 & 6.77 \\
Electron affinity $(\mathrm{eV})$ & 3.13 & 3.43 & 3.65 & 3.72 \\
Mulliken electronegativity & 4.57 & 4.95 & 5.11 & 5.25 \\
Softness & 0.695 & 0.659 & 0.683 & 0.654 \\
Hardness & 1.437 & 1.517 & 1.464 & 1.529 \\
Chemical potential (eV/mol) & -4.57 & -4.95 & -5.11 & -5.25 \\
Electrophilicity index & 7.27 & 8.07 & 8.93 & 9.00 \\
\hline
\end{tabular}

Figures 2 and 3 depict the layouts of the receptors under investigation. and their interactions with the studied ligands. Molecular docking revealed that compounds $\mathbf{5 d}$, $\mathbf{9 c}$, and $\mathbf{9 d}$ are the best ligands for SAP2 of Candida albicans, FabI of S. aureus, and FabI of $P$. aeruginosa, respectively. The calculated docking scores were found to be -11.35 , -11.30 and $-11.36 \mathrm{kcal} / \mathrm{mol}$ for SAP2 of C. albicans $/ \mathbf{5 d}, \mathrm{FabI}$ of $S$. aureus $/ \mathbf{9 c}$ and FabI of P. aeruginosa/9d, respectively. 


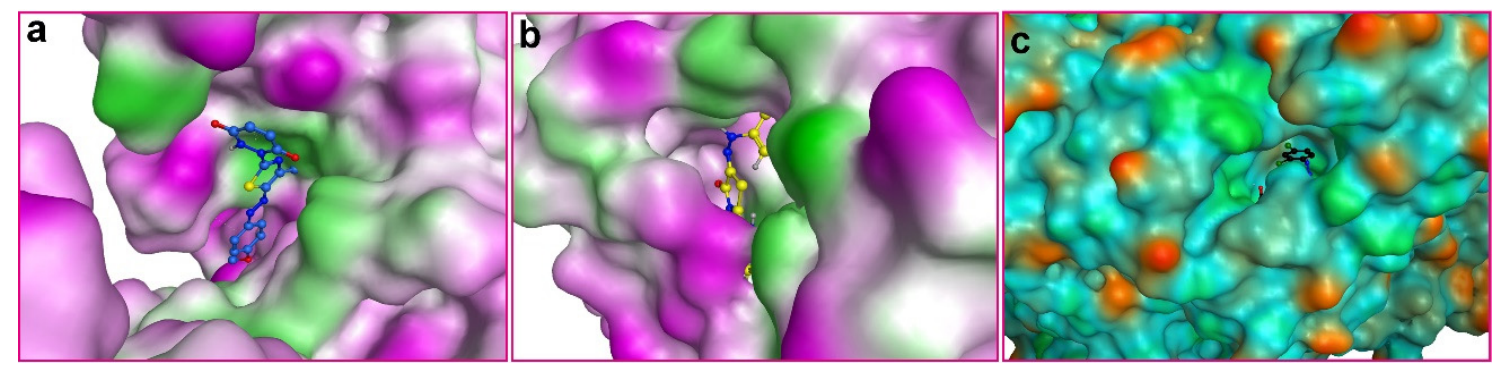

Figure 2. Structure of receptor molecules with the best fitting ligand molecules from the investigated set of ligands. (a) SAP2 of C. albicans/5d, (b) FabI of S. aureus/9c and (c) FabI of P. aeruginosa/9d.

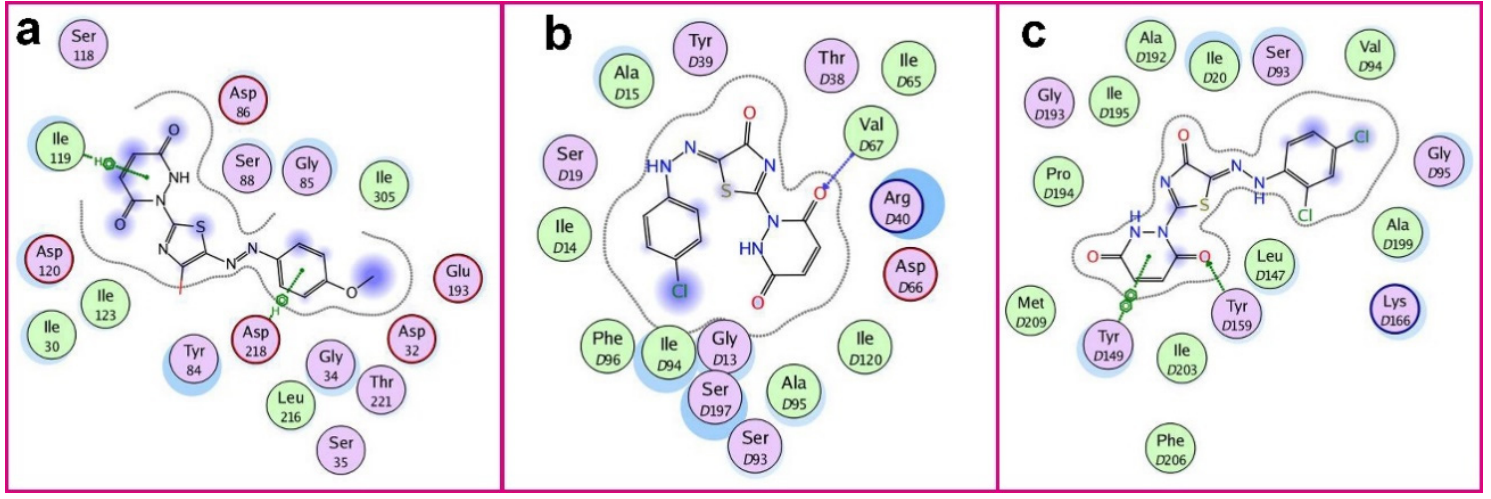

Figure 3. Ligand interaction diagrams for the best fitting ligand molecules showing the amino acid residues of the receptor active site and their interaction with the ligands. (a) SAP2 of C. albicans/5d, (b) FabI of S. aureus/9c and (c) FabI of P. aeruginosa/9d.

The in silico studies revealed that the of interaction of ligand 5d with SAP2 of C. albicans occurs via the hydrogen-aryl interaction between the aryl group of the ligand and the Asp 218 residue, and between the quinoid ring of the ligand and the Ile 119 amino acid. Whereas ligand $9 \mathrm{c}$ interacts with FabI of $S$. aureus through hydrogen bonding with Val D67 amino acid residue. In addition, compound 9d interacts with FabI of P. aeruginosa by aryl interaction with Tyr D149 and via the formation of a hydrogen bond with Tyr D159.

By comparing the results of in vitro XTT assay with those of the molecular docking study, it can be obviously noticed that there is an excellent agreement between them. For instance, compound $\mathbf{5 d}$, which shows the best docking score with SAP2 of $C$. albicans, is active against both $C$. albicans and S. aureus as shown in Table 1 . In addition, ligand $9 \mathbf{c}$, which demonstrated the best binding to Fab I of S. aureus, was found to be inactive against all microorganisms but $S$. aureus, as indicated from the XTT assay; thus, confirming the accuracy of the docking studies. Furthermore, compound $\mathbf{9 d}$ interestingly demonstrated a better antimicrobial activity against $P$. aeruginosa $(\mathrm{MIC}=0.24 \mu \mathrm{g} / \mathrm{mL}$ ) than the standard molecule, vancomycin (MIC $=0.49 \mu \mathrm{g} / \mathrm{mL}$ ). This agrees with the activity predicted from docking which revealed that ligand 10d has the best docking score $(-11.36 \mathrm{kcal} / \mathrm{mol})$ amongst all the theoretically studied ligands.

\section{Materials and Methods}

\subsection{General Experimental Procedures}

Melting points were measured with an Electrothermal IA 9000 series digital melting point apparatus. IR spectra were recorded in potassium bromide discs on PyeUnicamSP 3300 and Shimadzu FTIR 8101 PC infrared spectrophotometers. NMR spectra were recorded on a Varian Mercury VX-300 NMR spectrometer operating at $300 \mathrm{MHz}$ $\left({ }^{1} \mathrm{HNMR}\right)$ and run in deuterated dimethylsulfoxide (DMSO- $\left.d_{6}\right)$. Chemical shifts were related to that of the solvent. Mass spectra were recorded on a Shimadzu GCeMS-QP1000 
EX mass spectrometer at $70 \mathrm{eV}$. Elemental analyzes were measured by using a German made ElementarVario LIII CHNS analyzer. Irradiation was done in an ultrasonicator, (Electric supply: 230 v, A.C. $50 \mathrm{~Hz}$, 1phase; Ultrasonic frequency: $36 \mathrm{KHz}$; Ultrasonic power: $100 \mathrm{~W}$ ). Maleic anhydride 1, thiosemicarbazide 2, chitosan, aniline and pyridine were purchased from Sigma Aldrich Kingdom of Saudi Arabia and were used without further purification. Hydrazonoyl halides 3a-f, 7a-e and bis-hydrazonoyl halides 12a,b were prepared according to the reported methods [50,51].

\subsection{Synthesis of Thiazole Derivatives $\mathbf{5 a}-\mathbf{f}$, and $\mathbf{9 a}-\mathbf{e}$}

An equivalent amount of glacial acetic acid $(0.5 \mathrm{~mL})$ was added to a solution of maleic anhydride 1 (0.98 g, $1 \mathrm{mmol})$, thiosemicarbazide $2(0.92 \mathrm{~g}, 1 \mathrm{mmol})$ in ethanol $(20 \mathrm{~mL})$. The reaction mixture was heated in microwave oven at $500 \mathrm{~W}$ and $150{ }^{\circ} \mathrm{C}$ for $2 \mathrm{~min}$. Then, the appropriate hydrazonoyl halides $3 \mathbf{a}-\mathbf{f}$ or $7 \mathbf{a}-\mathbf{e}$ and chitosan $(0.1 \mathrm{~g})$ were added, the reaction mixture was further heated in microwave oven at $500 \mathrm{~W}$ and $150{ }^{\circ} \mathrm{C}$ until all the starting material was consumed (4-8 min. as monitored by TLC). The hot solution was filtered to remove chitosan and excess solvent was removed under reduced pressure. The reaction mixture was triturated with methanol and the product separated was filtered, washed with methanol, dried and recrystallized from EtOH or DMF to give products $5 \mathbf{a}-\mathbf{f}$ and $\mathbf{9 a}-\mathbf{e}$, respectively. The analytical and spectral data of the products $\mathbf{5 a - f}$ and $\mathbf{9 a - e}$ are listed below.

3.2.1. 1-(4-Methyl-5-(phenyldiazenyl)thiazol-2-yl)-1,2-dihydropyridazine-3,6-dione) (5a)

Red fine crystals; m.p. $184-186{ }^{\circ} \mathrm{C}$ (DMF). Anal. Calcd. for $\mathrm{C}_{14} \mathrm{H}_{11} \mathrm{~N}_{5} \mathrm{O}_{2} \mathrm{~S}$ (313.33): C 53.67; H, 3.54; N, 22.35. Found C, 53.55; H, 3.35; N, 22.14\%. MS m/z (\%) $313\left(\mathrm{M}^{+}, 12\right), 250$ (7), 233 (18), 149 (23), 133 (30), 128 (41), 113 (60), 98 (39), 73 (100), 65 (41), 55 (91); ${ }^{1} \mathrm{H}-\mathrm{NMR}$ $\left(\mathrm{DMSO}-d_{6}\right): \delta 2.56\left(\mathrm{~s}, 3 \mathrm{H}, \mathrm{CH}_{3}\right), 6.24(\mathrm{~d}, J=12 \mathrm{~Hz}, 1 \mathrm{H}, \mathrm{CH}=\mathrm{CH}), 6.66(\mathrm{~d}, J=12 \mathrm{~Hz}, 1 \mathrm{H}$, $\mathrm{CH}=\mathrm{CH}), 7.01-7.56$ (m, 5H, Ar-H), 10.62 (br s, 1H, NH) ppm; ${ }^{13} \mathrm{C}-\mathrm{NMR}\left(\mathrm{DMSO}-d_{6}\right): \delta 19.5$ $\left(\mathrm{CH}_{3}\right), 109.9,114.1,120.7,128.6,129.9,131.5,132.3,139.3,143.4(\mathrm{Ar}-\mathrm{C}$ and $\mathrm{C}=\mathrm{N}), 156.7,159.4$ $(2 \mathrm{C}=\mathrm{O})$ ppm; IR (KBr): $v 3435(\mathrm{NH}), 3049,2926(\mathrm{C}-\mathrm{H}), 1668,1654(2 \mathrm{C}=\mathrm{O}) \mathrm{cm}^{-1}$.

\subsubsection{1-(4-Methyl-5-(p-tolyldiazenyl)thiazol-2-yl)-1,2-dihydropyridazine-3,6-dione) (5b)}

Dark red fine crystals; m.p. $171-173{ }^{\circ} \mathrm{C}(\mathrm{EtOH}) ;$ Anal. Calcd. for $\mathrm{C}_{15} \mathrm{H}_{13} \mathrm{~N}_{5} \mathrm{O}_{2} \mathrm{~S}$ (327.36): C, 55.04; H, 4.00; N, 21.39. Found C, 55.35; H, 3.70; N, 21.18\%. MS m/z (\%) 327 $\left(\mathrm{M}^{+}, 5\right), 270(14), 199$ (16), 159 (77), 133 (9), 106 (76), 91 (100), 77 (43), 57 (33); ${ }^{1} \mathrm{H}-\mathrm{NMR}$ (DMSO- $\left.d_{6}\right): \delta 2.36\left(\mathrm{~s}, 3 \mathrm{H}, \mathrm{CH}_{3}\right), 2.56\left(\mathrm{~s}, 3 \mathrm{H}, \mathrm{CH}_{3}\right), 6.23(\mathrm{~d}, J=12 \mathrm{~Hz}, 1 \mathrm{H}, \mathrm{CH}=\mathrm{CH}), 6.52(\mathrm{~d}$, $J=12 \mathrm{~Hz}, 1 \mathrm{H}, \mathrm{CH}=\mathrm{CH}), 7.15-7.31(\mathrm{~m}, 4 \mathrm{H}, \mathrm{Ar}-\mathrm{H}), 10.66$ (br s, 1H, NH) ppm; IR (KBr): $v$ $3429(\mathrm{NH}), 3027,2921(\mathrm{C}-\mathrm{H}), 1690,1654(2 \mathrm{C}=\mathrm{O}) \mathrm{cm}^{-1}$.

\subsubsection{1-(4-Methyl-5-(m-tolyldiazenyl)thiazol-2-yl)-1,2-dihydropyridazine-3,6-dione) (5c)}

Dark red fine crystals; m.p. $185-187^{\circ} \mathrm{C}$. Anal. Calcd. for $\mathrm{C}_{15} \mathrm{H}_{13} \mathrm{~N}_{5} \mathrm{O}_{2} \mathrm{~S}$ (327.36): C, 55.04; H, 4.00; N, 21.39. Found C, 55.25; H, 3.79; N, 21.17\%. MS m/z (\%) $327\left(\mathrm{M}^{+}, 8\right), 222(48)$, 129 (21), 91 (58), 77 (36), 63 (100). ${ }^{1} \mathrm{H}-\mathrm{NMR}$ (DMSO-d $): \delta 2.34\left(\mathrm{~s}, 3 \mathrm{H}, \mathrm{CH}_{3}\right), 2.45\left(\mathrm{~s}, 3 \mathrm{H}, \mathrm{CH}_{3}\right)$, $6.23(\mathrm{~d}, \mathrm{~J}=12 \mathrm{~Hz}, 1 \mathrm{H}, \mathrm{CH}=\mathrm{CH}), 6.48$ (d, $\mathrm{J}=12 \mathrm{~Hz}, 1 \mathrm{H}, \mathrm{CH}=\mathrm{CH}), 7.06-7.64(\mathrm{~m}, 4 \mathrm{H}, \mathrm{Ar}-\mathrm{H})$, 10.93 (br s, 1H, NH); IR (KBr): $v 3433$ (NH), 3011, $2923(\mathrm{C}-\mathrm{H}), 1683,1669(2 \mathrm{C}=\mathrm{O}) \mathrm{cm}^{-1}$.

3.2.4. 1-(5-((4-Methoxyphenyl)diazenyl)-4-methylthiazol-2-yl)-1,2-dihydropyridazine-3,6dione $(5 d)$

Dark red fine crystals; m.p. 170-172 ${ }^{\circ} \mathrm{C}$ (DMF). Anal. Calcd. for $\mathrm{C}_{15} \mathrm{H}_{13} \mathrm{~N}_{5} \mathrm{O}_{3} \mathrm{~S}$ (343.07): C, 52.47; H, 3.82; N, 20.40. Found C, 52.48; H, 3.65; N, 20.23\%. MS m/z (\%) $343\left(\mathrm{M}^{+}, 3\right), 313$ (6), 199 (5), 129 (11), 108 (15), 97 (27), 73 (40), 57 (100). ${ }^{1} \mathrm{H}-\mathrm{NMR}$ (DMSO-d $)$ ): $\delta 2.66$ (s, 3H, $\left.\mathrm{CH}_{3}\right), 3.79\left(\mathrm{~s}, 3 \mathrm{H}, \mathrm{OCH}_{3}\right), 6.23(\mathrm{~d}, \mathrm{~J}=12 \mathrm{~Hz}, 1 \mathrm{H}, \mathrm{CH}=\mathrm{CH}), 6.62(\mathrm{~d}, \mathrm{~J}=12 \mathrm{~Hz}, 1 \mathrm{H}, \mathrm{CH}=\mathrm{CH})$, 7.03-7.86 (m, 4H, Ar-H), 10.87 (br s, 1H, NH) ppm; ${ }^{13} \mathrm{C}-\mathrm{NMR}\left(\mathrm{DMSO}-d_{6}\right): \delta 19.1\left(\mathrm{CH}_{3}\right)$, $55.3\left(\mathrm{OCH}_{3}\right), 110.3,113.6,114.5,126.9,127.2,128.7,132.7,149.6,153.7$ (Ar-C), 157.1, 159.1 $(2 \mathrm{C}=\mathrm{O}) \mathrm{ppm}$; IR $(\mathrm{KBr}): v 3423(\mathrm{NH}), 3022,2924(\mathrm{C}-\mathrm{H}), 1676,1659(2 \mathrm{C}=\mathrm{O}) \mathrm{cm}^{-1}$. 
3.2.5. 1-(5-((4-Chlorophenyl)diazenyl)-4-methylthiazol-2-yl)-1,2-dihydropyridazine-3,6dione (5e)

Dark red fine crystals; m.p. $195-197{ }^{\circ} \mathrm{C}$ (DMF). Anal. Calcd. for $\mathrm{C}_{14} \mathrm{H}_{10} \mathrm{ClN}_{5} \mathrm{O}_{2} \mathrm{~S}$ (397.04): C, 48.35; H, 2.90; N, 20.14. Found C, 48.75; H, 2.74; N, 19.98\%; MS m/z (\%) $397\left(\mathrm{M}^{+}\right.$, 12), 283 (4), 267 (22), 185 (4), 152 (8), 129 (26), 111 (60), 99 (66), 86 (61), 57 (100); ${ }^{1} \mathrm{H}-\mathrm{NMR}$ $\left(\mathrm{DMSO}-d_{6}\right): \delta 2.56\left(\mathrm{~s}, 3 \mathrm{H}, \mathrm{CH}_{3}\right), 6.27(\mathrm{~d}, J=12 \mathrm{~Hz}, 1 \mathrm{H}, \mathrm{CH}=\mathrm{CH}), 6.64(\mathrm{~d}, J=12 \mathrm{~Hz}, 1 \mathrm{H}$, $\mathrm{CH}=\mathrm{CH}$ ), 7.26-8.12 (m, 4H, Ar-H), 10.84 (br s, 1H, NH) ppm; IR (KBr): $v 3433$ (NH), 3042, $2925(\mathrm{C}-\mathrm{H}), 1671,1657(2 \mathrm{C}=\mathrm{O}) \mathrm{cm}^{-1}$.

3.2.6. 1-(5-((4-Bromophenyl)diazenyl)-4-methylthiazol-2-yl)-1,2-dihydropyridazine-3,6dione $(5 \mathbf{f})$

Brown fine crystals; m.p. 207-209 ${ }^{\circ} \mathrm{C}$ (DMF). Anal. Calcd. for $\mathrm{C}_{14} \mathrm{H}_{10} \mathrm{BrN}_{5} \mathrm{O}_{2} \mathrm{~S}$ (392.23): C, 42.87; H, 2.57; N, 17.86. Found C, 43.21; H, 2.25; N, 17.55\%. MS m/z (\%) $392\left(\mathrm{M}^{+}, 2\right), 325$ (53), 274 (11), 171 (25), 129 (15), 91 (57), 86 (89), 73 (64), 57 (100); ${ }^{1} \mathrm{H}-\mathrm{NMR}$ (DMSO- $\left.d_{6}\right): \delta 2.43$ $\left(\mathrm{s}, 3 \mathrm{H}, \mathrm{CH}_{3}\right), 6.12(\mathrm{~d}, \mathrm{~J}=12 \mathrm{~Hz}, 1 \mathrm{H}, \mathrm{CH}=\mathrm{CH}), 6.46(\mathrm{~d}, \mathrm{~J}=12 \mathrm{~Hz}, 1 \mathrm{H}, \mathrm{CH}=\mathrm{CH}), 7.39-8.20(\mathrm{~m}$, 4H, Ar-H), 11.23 (br s, 1H, NH) ppm; IR (KBr): v 3434 (NH), 3032, 2923 (C-H), 1685, 1660 $(2 \mathrm{C}=\mathrm{O}) \mathrm{cm}^{-1}$.

3.2.7. 1-(4-Oxo-5-(2-phenylhydrazineylidene)-4,5-dihydrothiazol-2-yl)-1,2dihydropyridazine-3,6-dione (9a)

Yellow fine crystals; m.p. $161-163{ }^{\circ} \mathrm{C}(\mathrm{EtOH})$. Anal. Calcd. for $\mathrm{C}_{13} \mathrm{H}_{9} \mathrm{~N}_{5} \mathrm{O}_{3} \mathrm{~S}(315.31)$ : C, 49.52; H, 2.88; N, 22.21. Found C, 49.70; H, 2.57; N, 21.88\%. MS m/z (\%) $315\left(\mathrm{M}^{+}, 7\right), 307$ (100), 279 (22), 150 (14), 104 (10), 92 (67), 77 (35), 65 (29); ${ }^{1} \mathrm{H}-\mathrm{NMR}$ (DMSO-d $): \delta 6.20$ (d, $J=12 \mathrm{~Hz}, 1 \mathrm{H}, \mathrm{CH}=\mathrm{CH}), 6.41(\mathrm{~d}, J=12 \mathrm{~Hz}, 1 \mathrm{H}, \mathrm{CH}=\mathrm{CH}), 7.04-7.82(\mathrm{~m}, 5 \mathrm{H}, \mathrm{Ar}-\mathrm{H}), 10.75$, 11.00 (2br s, 2H, 2NH) ppm; ${ }^{13} \mathrm{C}-\mathrm{NMR}$ (DMSO-d 6 ): $\delta 110.3,116.3,117.9,123.1,129.0,130.3$, 131.5, 147.7 (Ar-C and C=N), 158.2, 161.7, $172.8(3 \mathrm{C}=\mathrm{O})$ ppm; IR (KBr): $v$ 3429, $3178(2 \mathrm{NH})$, 3040, $2975(\mathrm{C}-\mathrm{H}), 1706,1680,1653(3 \mathrm{C}=\mathrm{O}) \mathrm{cm}^{-1}$.

3.2.8. 1-(4-Oxo-5-(2-(p-tolyl)hydrazineylidene)-4,5-dihydrothiazol-2-yl)-1,2dihydropyridazine-3,6-dione (9b)

Yellow fine crystals; m.p. $154-156{ }^{\circ} \mathrm{C}(\mathrm{EtOH})$. Anal. Calcd. for $\mathrm{C}_{14} \mathrm{H}_{11} \mathrm{~N}_{5} \mathrm{O}_{3} \mathrm{~S}$ (329.33): C, 51.06; H, 3.37; N, 21.27. Found C, 51.35; H, 3.06; N, 21.03\%. MS m/z (\%) $329\left(\mathrm{M}^{+}, 7\right), 263$ (12), 155 (18), 125 (4), 111 (10), 101 (16), 97 (15), 86 (100), 58 (46); ${ }^{1} \mathrm{H}-\mathrm{NMR}$ (DMSO- $\left.d_{6}\right): \delta(\mathrm{s}$, $\left.3 \mathrm{H}, \mathrm{CH}_{3}\right), \delta 6.23(\mathrm{~d}, \mathrm{~J}=12 \mathrm{~Hz}, 1 \mathrm{H}, \mathrm{CH}=\mathrm{CH}), 6.45(\mathrm{~d}, J=12 \mathrm{~Hz}, 1 \mathrm{H}, \mathrm{CH}=\mathrm{CH}), 7.40-8.00(\mathrm{~m}$, $4 \mathrm{H}, \mathrm{Ar}-\mathrm{H}), 10.54,10.79$ (2 br s, 2H, 2NH); IR (KBr): v 3431, 3278 (2NH), 3030, 2979 (C-H), $1705,1679,1629(3 \mathrm{C}=\mathrm{O}) \mathrm{cm}^{-1}$.

3.2.9. 1-(5-(2-(4-Chlorophenyl)hydrazineylidene)-4-oxo-4,5-dihydrothiazol-2-yl)-1,2dihydropyridazine-3,6-dione (9c)

Yellow fine crystals; m.p. $170-172{ }^{\circ} \mathrm{C}(\mathrm{EtOH})$. Anal. Calcd. for $\mathrm{C}_{13} \mathrm{H}_{8} \mathrm{ClN}_{5} \mathrm{O}_{3} \mathrm{~S}$ (349.75): C, 44.64; H, 2.31; N, 20.02. Found C, 44.93; H, 2.01; N, 19.70\%. MS m/z (\%) $351\left(\mathrm{M}^{+}+2,2\right)$, $349\left(\mathrm{M}^{+}, 7\right), 310$ (5), 239 (5), 152 (10), 125 (36), 111 (31), 83 (39), 69 (58), 57 (100); ${ }^{1} \mathrm{H}-\mathrm{NMR}$ $\left(\mathrm{DMSO}-d_{6}\right): \delta 6.30(\mathrm{~d}, J=12 \mathrm{~Hz}, 1 \mathrm{H}, \mathrm{CH}=\mathrm{CH}), 6.54(\mathrm{~d}, J=12 \mathrm{~Hz}, 1 \mathrm{H}, \mathrm{CH}=\mathrm{CH}), 6.93-7.58$ (m, 4H, Ar-H), 9.96, 12.68 (2 br s, 2H, 2NH) ppm; IR (KBr): v 3431, 3219 (2NH), 3039, 2989 $(\mathrm{C}-\mathrm{H}), 1705,1657,1629(3 \mathrm{C}=\mathrm{O}) \mathrm{cm}^{-1}$.

3.2.10. 1-(5-(2-(2,4-Dichlorophenyl)hydrazineylidene)-4-oxo-4,5-dihydrothiazol-2-yl)-1,2dihydropyridazine-3,6-dione (9d)

Yellow fine crystals; m.p. $149-151{ }^{\circ} \mathrm{C}(\mathrm{EtOH})$. Anal. Calcd. for $\mathrm{C}_{13} \mathrm{H}_{7} \mathrm{Cl}_{2} \mathrm{~N}_{5} \mathrm{O}_{3} \mathrm{~S}$ (382.19): C, 40.64; H, 1.84; N, 18.23. Found C, 40.93; H, 1.55; N, 18.00\%. MS m/z (\%) 382 $\left(\mathrm{M}^{+}, 3\right), 375$ (100), 349 (12), 347 (18), 218 (5), 160 (21), 133 (21), 112 (9), 82 (12); ${ }^{1} \mathrm{H}-\mathrm{NMR}$ $\left(\mathrm{DMSO}-d_{6}\right): \delta 6.30(\mathrm{~d}, J=12 \mathrm{~Hz}, 1 \mathrm{H}, \mathrm{CH}=\mathrm{CH}), 6.54(\mathrm{~d}, J=12 \mathrm{~Hz}, 1 \mathrm{H}, \mathrm{CH}=\mathrm{CH}), 6.93-7.58$ (m, 3H, Ar-H), 9.96, 12.68 (2 br s, 2H, 2NH) ppm; IR (KBr): v 3383, 3219 (2NH), 3039, 2983 $(\mathrm{C}-\mathrm{H}), 1696,1657,1641(3 \mathrm{C}=\mathrm{O}) \mathrm{cm}^{-1}$. 
3.2.11. 1-(5-(2-(4-Nitrophenyl)hydrazineylidene)-4-oxo-4,5-dihydrothiazol-2-yl)-1,2dihydropyridazine-3,6-dione (9e)

Yellow fine crystals; m.p. $159-161^{\circ} \mathrm{C}(\mathrm{EtOH})$. Anal. Calcd. for $\mathrm{C}_{13} \mathrm{H}_{8} \mathrm{~N}_{6} \mathrm{O}_{5} \mathrm{~S}(360.30)$ : $\mathrm{C}, 43.34 ; \mathrm{H}, 2.24 ; \mathrm{N}, 23.33$. Found C, 43.42; H, 2.09; N, 23.15\%; MS m/z (\%) $360\left(\mathrm{M}^{+}, 12\right)$, 328 (9), 259 (4), 221 (3), 180 (4), 152 (4), 129 (12), 113 (40), 97 (27), 87 (38), 71 (48), 59 (100); ${ }^{1} \mathrm{H}-\mathrm{NMR}\left(\mathrm{DMSO}-\mathrm{d}_{6}\right): \delta 2.26\left(\mathrm{~s}, 3 \mathrm{H}, \mathrm{CH}_{3}\right), 6.27(\mathrm{~d}, J=12 \mathrm{~Hz}, 1 \mathrm{H}, \mathrm{CH}=\mathrm{CH}), 6.51(\mathrm{~d}, J=12$ $\mathrm{Hz}, 1 \mathrm{H}, \mathrm{CH}=\mathrm{CH}), 6.98-7.97$ (m, 4H, Ar-H), 10.54, 10.77 (2 br s, 2H, 2NH) ppm; IR (KBr): $v$ 3426, $3178(2 \mathrm{NH}), 3030,2922(\mathrm{C}-\mathrm{H}), 1703,1649,1632(3 \mathrm{C}=\mathrm{O}) \mathrm{cm}^{-1}$.

\subsection{Alternate Synthesis of Thiazole Derivative 5a}

3.3.1. Synthesis of 3,6-Dioxo-3,6-dihydropyridazine-1(2H)-carbothioamide (6)

An equivalent amount of glacial $\mathrm{AcOH}(0.5 \mathrm{~mL})$ was added to an ethanolic solution of maleic anhydride $1(0.098 \mathrm{~g}, 1 \mathrm{mmol})$ and thiosemicarbazide $2(0.092 \mathrm{~g}, 1 \mathrm{mmol})$. The reaction mixture was heated in a microwave oven at $500 \mathrm{~W}$ and $150{ }^{\circ} \mathrm{C}$ for $2 \mathrm{~min}$. as monitored by TLC. The formed product was recrystallized from ethanol to give pure derivative 6 as white solid; m.p. $232-234{ }^{\circ} \mathrm{C}$. Anal. Calcd. for $\mathrm{C}_{5} \mathrm{H}_{5} \mathrm{~N}_{3} \mathrm{O}_{2} \mathrm{~S}$ (171.17): C, 35.08; H, 2.94; N, 24.55. Found C, 35.01; H, 2.84; N, 24.49\%; MS m/z (\%): $171\left(\mathrm{M}^{+}\right), 132(19)$, 107 (80), 87 (53), 57 (100); ${ }^{1} \mathrm{H}-\mathrm{NMR}$ (DMSO- $\left.d_{6}\right): \delta 6.19(\mathrm{~d}, J=12 \mathrm{~Hz}, 1 \mathrm{H}, \mathrm{CH}=\mathrm{CH}), 6.44$ $(\mathrm{d}, J=12 \mathrm{~Hz}, 1 \mathrm{H}, \mathrm{CH}=\mathrm{CH}), 9.30$ (br s, $\left.2 \mathrm{H}, \mathrm{NH}_{2}\right), 10.46$ (br s, 1H, NH) ppm; IR (KBr): $v$ $3387-3314,3258\left(\mathrm{NH}_{2}\right.$ and $\left.\mathrm{NH}\right), 3149,2963(\mathrm{C}-\mathrm{H}), 1687,1634(2 \mathrm{C}=\mathrm{O}) \mathrm{cm}^{-1}$.

\subsubsection{Reaction of $\mathbf{6}$ with $3 \mathbf{a}$}

Equimolar amounts of carbothioamide $7(0.171 \mathrm{~g}, 1 \mathrm{mmol})$ and 2-oxo-N-phenylpropane hydrazonoyl chloride 3a $(0.196 \mathrm{~g}, \mathrm{mmol})$ in ethanol $(15 \mathrm{~mL})$ containing an equivalent amount of chitosan $(0.1 \mathrm{~g})$ was heated in a microwave oven at $500 \mathrm{~W}$ and $150{ }^{\circ} \mathrm{C}$ for $5 \mathrm{~min}$. as monitored by TLC. The hot solution was filtered to remove chitosan and excess solvent was removed under reduced pressure, gave product identical in all respects (m.p., mixed m.p. and IR spectra) with compounds 5 a.

\subsection{Alternate Synthesis of Thiazole Derivative 9a}

3.4.1. 1-(4-Oxo-4,5-dihydrothiazol-2-yl)-1,2-dihydropyridazine-3,6-dione (11)

To a solution of maleic anhydride $\mathbf{1}(0.098 \mathrm{~g}, 1 \mathrm{mmol})$, thiosemicarbazide $2(0.092 \mathrm{~g}$, $1 \mathrm{mmol})$, and ethyl 2-bromoacetate $10(0.0165 \mathrm{~g}, 1 \mathrm{mmol})$ in ethanol $(15 \mathrm{~mL})$, an equivalent amount of chitosan $(0.1 \mathrm{~g})$ was added. The reaction mixture was heated in microwave oven at $500 \mathrm{~W}$ and $150{ }^{\circ} \mathrm{C}$ for $4 \mathrm{~min}$. as monitored by TLC. The hot solution was filtered to remove chitosan and excess solvent was removed under reduced pressure. The reaction mixture was triturated with methanol and the product separated was filtered, washed with methanol, dried and recrystallized from ethanol to give thiazolone products $\mathbf{1 1}$ as yellow solid; m.p. 157-159 ${ }^{\circ} \mathrm{C}$; Anal. Calcd. for $\mathrm{C}_{7} \mathrm{H}_{5} \mathrm{~N}_{3} \mathrm{O}_{3} \mathrm{~S}$ (211.01): C, 39.81; H, 2.39; N, 19.90. Found C, 40.21; H, 2.17; N, 19.64\%. MS m/z (\%) $211\left(\mathrm{M}^{+}, 16\right), 149$ (19), 117 (63), 92 (66), 57 (100); ${ }^{1} \mathrm{H}-\mathrm{NMR}$ (DMSO- $\left.d_{6}\right): \delta 3.82\left(\mathrm{~s}, 2 \mathrm{H}, \mathrm{CH}_{2}\right), 6.22(\mathrm{~d}, J=12 \mathrm{~Hz}, 1 \mathrm{H}, \mathrm{CH}=\mathrm{CH}), 6.53(\mathrm{~d}$, $J=12 \mathrm{~Hz}, 1 \mathrm{H}, \mathrm{CH}=\mathrm{CH}), 10.25(\mathrm{~s}, 1 \mathrm{H}, \mathrm{NH}) \mathrm{ppm}$; IR (KBr): $v 3438(\mathrm{NH}), 3168,2987(\mathrm{C}-\mathrm{H})$, $1708,1650,1648(3 \mathrm{C}=\mathrm{O}) \mathrm{cm}^{-1}$.

\subsubsection{Coupling of $\mathbf{1 1}$}

To a solution of each of compound $\mathbf{1 0}(0.211 \mathrm{~g}, 1 \mathrm{mmol})$ with sodium acetate trihydrate in ethanol $(10 \mathrm{~mL})$ was added benzenediazonium chloride solution, (prepared as usual by diazotizing aniline $(1 \mathrm{mmol})$ in hydrochloric acid $(1 \mathrm{~mL}, 6 \mathrm{M})$ with sodium nitrite $(0.07 \mathrm{~g}$, $1 \mathrm{mmol}$ ) in $10 \mathrm{~mL}$ water) portion wise with stirring and cooling. After complete addition, the reaction mixture was left for $12 \mathrm{~h}$. in the refrigerator. The precipitate formed was collected by filtration, washed with water, dried and then recrystallized from EtOH to give the respective product identical in all respects with $9 a$. 


\subsection{Synthesis of Bis-Thiazole $\mathbf{1 3}$ and Bis-Thiazolone $\mathbf{1 4}$}

To a solution of maleic anhydride $\mathbf{1}(0.196 \mathrm{~g}, 2 \mathrm{mmol})$, thiosemicarbazide $2(0.184$ $\mathrm{g}, 2 \mathrm{mmol})$ in ethanol $(20 \mathrm{~mL})$, an equivalent amount of glacial acetic acid $(1 \mathrm{~mL})$ was added. The reaction mixture was heated in microwave oven at $500 \mathrm{~W}$ and $150{ }^{\circ} \mathrm{C}$ for $2 \mathrm{~min}$. Then, the appropriate bis-hydrazonoyl halides 12a,b (1 mmol for each) and chitosan $(0.2$ g) were added, the reaction mixture was further heated in microwave oven at $500 \mathrm{~W}$ and $150{ }^{\circ} \mathrm{C}$ until all the starting material was consumed ( $8 \mathrm{~min}$ as monitored by TLC). The hot solution was filtered to remove chitosan and excess solvent was removed under reduced pressure. The reaction mixture was triturated with methanol and the product separated was filtered, washed with methanol, dried and recrystallized from ethanol to give products 13 and 14 , respectively.

3.5.1. 1,1'-(([1,1'-Biphenyl]-4,4'-diylbis(diazene-2,1-diyl))bis(4-methylthiazole-5,2diyl))bis(1,2-dihydropyridazine-3,6-dione) (13)

Yellow fine crystals; m.p. $187-189^{\circ} \mathrm{C}$; Anal. Calcd. for $\mathrm{C}_{28} \mathrm{H}_{20} \mathrm{~N}_{10} \mathrm{O}_{4} \mathrm{~S}_{2}$ (624.11): C, 53.84; H, 3.23; N, 22.42. Found C, 54.04; H, 3.09; N, 22.27\%; MS m/z (\%) $624\left(\mathrm{M}^{+}, 22\right)$, 373 (13), 341 (10), 299 (2), 271 (21), 112 (20), 98 (39), 86 (67), 69 (45), 54 (100); ${ }^{1} \mathrm{H}-\mathrm{NMR}$ (DMSO- $\left.d_{6}\right): \delta 2.58\left(\mathrm{~s}, 6 \mathrm{H}, \mathrm{CH}_{3}\right), 6.27(\mathrm{~d}, J=12 \mathrm{~Hz}, 2 \mathrm{H}, \mathrm{CH}=\mathrm{CH}), 6.63(\mathrm{~d}, J=12 \mathrm{~Hz}, 2 \mathrm{H}$, $\mathrm{CH}=\mathrm{CH}), 7.43(\mathrm{~s}, 8 \mathrm{H}, \mathrm{Ar}-\mathrm{H}), 10.64(\mathrm{br} \mathrm{s}, 2 \mathrm{H}, 2 \mathrm{NH}) \mathrm{ppm} ;{ }^{13} \mathrm{C}-\mathrm{NMR}$ (DMSO- $\left.d_{6}\right): \delta 19.7$ $\left(\mathrm{CH}_{3}\right), 109.5,115.7,120.7,127.5,133.2,137.9,142.1,143.1,152.1(\mathrm{Ar}-\mathrm{C}$ and $\mathrm{C}=\mathrm{N}), 156.8,160.0$ $(2 \mathrm{C}=\mathrm{O})$ ppm; IR (KBr): v $3428(\mathrm{NH}), 2922(\mathrm{C}-\mathrm{H}), 1699,1659(2 \mathrm{C}=\mathrm{O}) \mathrm{cm}^{-1}$.

3.5.2. 1-(5-(2-(4'-(2-(2-(3,6-Dioxo-3,6-dihydropyridazin-1(2H)-yl)-4-oxothiazol-5(4H)ylidene)hydrazinyl)-[1,1'-biphenyl]-4-yl)hydrazineylidene)-4-oxo-4,5-dihydrothiazol-2yl)-1,2-dihydropyridazine-3,6-dione (14)

Yellow fine crystals; m.p. $198-200{ }^{\circ} \mathrm{C}$; Anal. Calcd. for $\mathrm{C}_{26} \mathrm{H}_{16} \mathrm{~N}_{10} \mathrm{O}_{6} \mathrm{~S}_{2}$ (628.60): C, 49.68; H, 2.57; N, 22.28. Found C, 49.59; H, 2.48; N, 22.10\%; MS m/z (\%) $628\left(\mathrm{M}^{+}, 4\right), 367(31)$, 334 (24), 313 (19), 294 (49), 236 (25), 184 (63), 139 (66), 97 (36), 71 (49), 55 (100); ${ }^{1} \mathrm{H}-\mathrm{NMR}$ $\left(\right.$ DMSO $\left.-d_{6}\right): \delta 6.29(\mathrm{~d}, J=12 \mathrm{~Hz}, 2 \mathrm{H}, \mathrm{CH}=\mathrm{CH}), 6.53(\mathrm{~d}, J=12 \mathrm{~Hz}, 2 \mathrm{H}, \mathrm{CH}=\mathrm{CH}), 7.52(\mathrm{~m}, 8 \mathrm{H}$, Ar-H), 10.37, 10.79 (2 br s, 4H, 2NH) ppm; IR (KBr): v 3422, 3032 (2NH), 2978, 2930 (C-H), $1683,1655,1636(3 \mathrm{C}=\mathrm{O}) \mathrm{cm}^{-1}$.

\subsection{In Vitro XTT Assay}

XTT assay, a non-radioactive colorimetric assay system, is usually used for measuring cell viability, proliferation and cytotoxicity through the measurement of cellular metabolic activity. This test depends on the reduction of a yellow tetrazolium salt (XTT dye) to an orange formazan dye by metabolically active cells. The minimal inhibitory concentration (MIC) values, which represent the lowest concentrations of samples or standard drugs (Vancomycine for bacteria and Amphotricine B for fungi) that completely inhibit the microbial growth. MICs were determined using the microdilution method. The bacterial inoculum was prepared, and the suspensions were adjusted to $10^{6} \mathrm{CFU} / \mathrm{mL}$. The samples under investigation and the standard drugs were prepared in dimethyl sulfoxide (DMSO) and subsequent twofold dilutions were performed in a 96-well plate. Each well of the microplate included $40 \mu \mathrm{L}$ of the growth medium (Brain Heart Infusion, BHI), $10 \mu \mathrm{L}$ of the inoculum and $50 \mu \mathrm{L}$ of the investigated compounds diluted to final concentrations of $(1000-0.12 \mu \mathrm{g} / \mathrm{mL})$, and DMSO was used as a negative control. The plates were incubated at $37^{\circ} \mathrm{C}$ for $24 \mathrm{~h}$. Thereafter, $40 \mu \mathrm{L}$ of tetrazolium salt \{2,3-bis[2-methyloxy4-nitro-5-sulfophenyl]-2H-tetrazolium-5-car-boxanilide (XTT)\} were added. The plates were incubated in dark for $1 \mathrm{~h}$ at $37^{\circ} \mathrm{C}$, after which colorimetric change in the XTT reduction assay was measured using a microtiter plate reader (Tecan Sunrise absorbance reader; Tecan UK, Reading, United Kingdom) at $492 \mathrm{~nm}$. The MIC was detected as the lowest concentration capable of causing the largest color change compared to the negative control [52]. 


\subsection{In Silico Studies}

The electronic properties of the synthesized derivatives that demonstrated the best biological activities in the in vitro XTT assay were investigated with density functional theory calculations. The calculations were carried out with the aid of Gaussian 09 [53]. The geometry of the studied molecules was fully optimized using B3LYP/6-311G functional and the obtained molecular orbitals were visualized.

Molecular docking was used to investigate the interaction of the best biologically active molecules with the microbial receptors. We selected the most probable bacterial/fungal proteins that can be affected by the synthesized thiazole ligands based on the results previously reported in the literature. Molecular docking was carried out with the aid of the Molecular Operating Environment (MOE) 2014 software [54]. The geometry-optimized compounds that demonstrated the lowest MIC values in the XTT assay were selected and docked with the corresponding receptors. High-resolution 3D molecular structures of the receptors Secreted Aspartic Proteinase (SAP2; C. albicans; PDB ID: 1EAG), Enoylacyl Carrier Protein Reductase (fabI; S. aureus; PDB ID: 3GR6) and Enoyl-acyl Carrier Protein Reductase (FabI; P. aerugiosa; PDB ID: 4NR0) were obtained from the Protein Data Bank (PDB).

\section{Conclusions}

In summary, we have developed a new green methodology and synthesized several novel 1-thiazolylpyridazine derivatives by MWI in high, efficient yields and short reaction time. Additionally, the antimicrobial activities of the candidate lead molecules were tested against $S$. aureus, $P$. aeruginosa and C. albicans using the XTT assay and compounds with the highest activity in terms of MIC were docked with the corresponding microorganisms' receptors. The results depict that compound $\mathbf{5 d}$ shows comparable biological activities to these of the standard antibacterial/antifungal drugs in case of S. aureus and C. albicans. In addition, compound $\mathbf{9 d}$ demonstrated the highest activity against $P$. aeruginosa.

Author Contributions: S.M.G. and Z.A.M. conceived the experiment(s), S.M.G., M.M.E., A.S.A., A.S.A.D. and Z.A.M. conducted the experiment(s), S.A.-M., S.M.G., A.S.A., A.S.A.D. and Z.A.M. analyzed the results. All authors have read and agreed to the published version of the manuscript.

Funding: The authors extend their appreciation to the deanship of scientific research at King Khalid University for funding this work through a general research project under grant number (GRP-239-41).

Institutional Review Board Statement: Not applicable.

Informed Consent Statement: Not applicable.

Data Availability Statement: The data presented in this study are available on request from corresponding author.

Acknowledgments: The financial support by the Deanship of Scientific Research (GRP-239-41), King Khalid University, Saudi Arabia is gratefully acknowledged.

Conflicts of Interest: The authors declare that there is no conflict of interests regarding the publication of this paper.

Sample Availability: Samples of all synthesized compounds are available from the authors.

\section{References}

1. Cherng, S.C.; Huang, W.H.; Shiau, C.Y.; Lee, A.R.; Chou, T.C. Mechanisms of antiplatelet activity of PC-09, a newly synthesized pyridazinone derivative. Eur. J. Pharmacol. 2006, 532, 32-37. [CrossRef]

2. Rathish, I.G.; Javed, K.; Bano, S.; Ahmad, S.; Alam, M.S.; Pillai, K.K. Synthesis and blood glucose lowering effect of novel pyridazinone substituted benzenesulfonylurea derivatives. Eur. J. Med. Chem. 2009, 44, 2673-2678. [CrossRef]

3. Bansal, R.; Kumar, D.; Carron, R.; de la Calle, C. Synthesis and vasodilatory activity of some amide derivatives of 6-(4carboxymethyloxyphenyl)-4,5-dihydro-3(2H)-pyridazinone. Eur. J. Med. Chem. 2009, 44, 4441-4447. [CrossRef] [PubMed]

4. Moreau, S.; Coudert, P.; Rubat, C.; Vallee-Goyet, D.; Gardette, D.; Gramain, J.C.; Couquelet, J. Synthesis and anticonvulsant properties of triazolo- and imidazopyridazinyl carboxamides and carboxylic acids. Bioorg. Med. Chem. Lett. 1998, 6, 983-991. [CrossRef] 
5. Hallot, A.; Brodin, R.; Merlier, J.; Brochard, J.; Chambon, J.P.; Biziere, K. Synthesis and activity of 6-aryl-3-(hydroxypolymethyleneamino)pyridazines in animal models of epilepsy. J. Med. Chem. 1986, 29, 369-375. [CrossRef] [PubMed]

6. Meenakshi, D.; Pravin, S.; Ashok, B.; Kapil, J.; Rahul, D.; Pramod, S. In-vivo Anticonvulsant and In-vitro Antimycobacterial Activities of 6-Aryl Pyridazine-3(2H)-One Derivatives. Turk. J. Chem. 2009, 33, 1-7.

7. Shiradkar, M.R.; Ghodake, M.; Bothara, K.G.; Bhandari, S.V.; Nikalje, A.; Akula, K.C.; Desai, N.C.; Burange, P.J. Synthesis and anticonvulsant activity of clubbed thiazolidinone-barbituric acid and thiazolidinone-triazole derivatives. ARKIVOC 2007, 14, 58-74. [CrossRef]

8. Sivakumar, S.; Surendra, N.P.; James, P.S.; Suthakar, G. Anticonvulsant and Sedative-Hypnotic Activities of N-Acetyl/Methyl Isatin Derivatives. Sci. Pharm. 2008, 76, 621-636.

9. Quiroga, J.; Hernandez, P.; Insuasty, B.; Abonia, R.; Cobo, J.; Sanchez, A.; Nogueras, M.; Low, J.N. Control of the reaction between 2-aminobenzothiazoles and Mannich bases. Synthesis of pyrido[2,1- $b][1,3]$ benzothiazoles versus [1,3]benzothiazolo[2,3b]quinazolines. J. Chem. Soc. Perkin Trans. 1 2002, 4, 555. [CrossRef]

10. Hutchinson, I.; Jennings, S.A.; Vishnuvajjala, B.R.; Westwell, A.D.; Stevens, M.F.G. Antitumor benzothiazoles. 16. Synthesis and pharmaceutical properties of antitumor 2-(4-aminophenyl)benzothiazole amino acid prodrugs. J. Med. Chem. 2002, 45, 744. [CrossRef]

11. Sharma, R.N.; Xavier, F.P.; Vasu, K.K.; Chaturvedi, S.C.; Pancholi, S.S. Synthesis of 4-benzyl-1, 3-thiazole derivatives as potential anti-inflammatory agents: An analogue-based drug design approach. J. Enz. Inhib. Med. Chem. 2009, 24, 890. [CrossRef] [PubMed]

12. Gomha, S.M.; Salah, T.A.; Hassaneen, H.M.E.; Abdel-aziz, H.; Khedr, M.A. Synthesis, characterization and molecular docking of novel bioactive thiazolyl-thiazole derivatives as promising cytotoxic antitumor drug. Molecules 2016, 21, 3. [CrossRef] [PubMed]

13. Dawood, K.M.; Gomha, S.M. Synthesis and anti-cancer activity of 1,3,4-thiadiazole and 1,3-thiazole derivatives having 1,3,4oxadiazole moiety. J. Heterocycl. Chem. 2015, 52, 1400. [CrossRef]

14. Badorc, A.; Bordes, M.F.; Cointet, P.D.; Savi, P.; Bernat, A.; Lale, A.; Petitou, M.; Maffrand, J.P.J.; Herbert, M. C-Terminal Modifications of Histidyl-N-benzylglycinamides To Give Improved Inhibition of Ras Farnesyltransferase, Cellular Activity, and Anticancer Activity in Mice. J. Med. Chem. 1997, 40, 3393. [CrossRef] [PubMed]

15. Rudolph, J.; Theis, H.; Hanke, R.; Endermann, R.; Johannsen, L. Geschke, seco-Cyclothialidines: New Concise Synthesis, Inhibitory Activity toward Bacterial and Human DNA Topoisomerases, and Antibacterial Properties. F.U.J. Med. Chem. 2001, 44, 619-626. [CrossRef]

16. Abdelhamid, A.O.; Shawali, A.; Gomha, S.M.; El-Enany, W.A.M.A. Synthesis and anti-microbial evaluation of some novel thiazole, 1,3,4-thiadiazole and pyrido[2,3-d][1,2,4]-triazolo[4,3-a]pyrimidine derivatives incorporating pyrazole moiety. Heterocycles 2015, 91, 2126. [CrossRef]

17. Murata, T.; Murai, M.; Ikeda, Y.; Miki, K.; Ohe, K. Pd- and Cu-catalyzed one-pot multicomponent synthesis of hetero alpha, alpha'-dimers of heterocycles. Org. Lett. 2012, 14, 2296-2299. [CrossRef]

18. Lalli, C.; Bouma, M.J.; Bonne, D.; Masson, G.; Zhu, J. Exploiting the divergent reactivity of alpha-isocyanoacetate: Multicomponent synthesis of 5-alkoxyoxazoles and related heterocycles. Chem. Eur. J. 2011, 17, 880-889. [CrossRef]

19. Zhang, S.; Zhang, W.-X.; Xi, Z. Efficient one-pot synthesis of N-containing heterocycles by multicomponent coupling of silicontethered diynes, nitriles, and isocyanides through intramolecular cyclization of iminoacyl-Zr intermediates. Chem. Eur. J. 2010, 16, 8419-8426. [CrossRef]

20. Lopez, C.; Zougagh, M.; Algarra, M.; Rodriguez-Castellon, E.; Campos, B.B.; Esteves da Silva, J.C.; Jimenez-Jimenez, J.; Rios, A. Microwave-assisted synthesis of carbon dots and its potential as analysis of four heterocyclic aromatic amines. Talanta 2015, 132, 845-850. [CrossRef]

21. Pawelczyk, A.; Zaprutko, L. Microwave assisted synthesis of unsaturated jasmone heterocyclic analogues as new fragrant substances. Eur. J. Med. Chem. 2009, 44, 3032-3039. [CrossRef] [PubMed]

22. Jeselnik, M.; Varma, R.S.; Polanc, S.; Kocevar, M. Catalyst-free reactions under solvent-free conditions: Microwave-assisted synthesis of heterocyclic hydrazones below the melting points of neat reactants. Chem. Commun. 2001, 21, 1716-1717. [CrossRef]

23. Al-Qalaf, F.; Mandani, F.; Abdelkhalik, M.M.; Bassam, A.A. Synthesis of 5-substituted 3-amino-1H-pyrazole-4-carbonitriles as precursors for microwave assisted regiospecific syntheses of pyrazolo[1,5-a]pyrimidines. Molecules 2009, 14, 78-88. [CrossRef] [PubMed]

24. Ezer, M.; Yildirim, L.T.; Bayro, O.; Verspohl, E.J.; Dundar, O.B. Synthesis and antidiabetic activity of morpholinothiazolyl-2,4thiazolidindione derivatives. J. Enzyme Inhib. Med. Chem. 2012, 27, 419-427. [CrossRef] [PubMed]

25. Qin, Y.; Zhao, W.; Yang, L.; Zhang, X.; Cui, Y. Chitosan-based heterogeneous catalysts for enantioselective Michael reaction. Chirality 2012, 24, 640-645. [CrossRef]

26. Watile, R.A.; Bhanage, B.M. Chitosan biohydrogel beads: A recyclable, biodegradable, heterogeneous catalyst for the regioselective synthesis of 5-aryl-2-oxazolidinones from carbon dioxides and aziridines at mild conditions. Ind. J. Chem. 2012, 51A, 1354-1360. [CrossRef]

27. Al-Matar, H.M.; Khalil, K.D.; Meier, H.; Kolshorn, H.; Elnagdi, M.H. Chitosan as heterogeneous catalyst in Michael additions: The reaction of cinnamonitriles with active methylene moieties and phenols. ARKIVOC 2008, 16, 288-301. [CrossRef]

28. Gomha, S.M.; Riyadh, S.M. Synthesis of triazolo[4,3-b][1,2,4,5]tetrazines and triazolo[3,4- $b][1,3,4]$ thiadiazines using chitosan as ecofriendly catalyst under microwave irradiation. ARKIVOC 2009, 11, 58-68. [CrossRef] 
29. Khalil, K.D.; Al-Matar, H.M.; Elnagdi, M.H. Chitosan as an eco-friendly heterogeneous catalyst for Michael type addition reactions. A simple and efficient route to pyridones and phthalazines. Eur. J. Chem. 2010, 1, 252-258. [CrossRef]

30. Guibal, E. Heterogeneous catalysis on chitosan-based materials: A review. Prog. Polym. Sci. 2005, 30, 71-109. [CrossRef]

31. Gomha, S.M.; Khalil, K.D.; El-Zanate, A.M.; Riyadh, S.M. A Facile Green Synthesis and anti-cancer activity of bisarylhydrazononitriles, triazolo[5,1-c][1,2,4]triazine, and 1,3,4-thiadiazoline. Heterocycles 2013, 87, 1109-1120.

32. Gomha, S.M.; Badrey, M.G.; Edrees, M.M. Heterocyclization of a bis-thiosemicarbazone of 2,5-diacetyl-3,4-disubstituted-thieno[2,3b]thiophene bis-thiosemicarbazones leading to bis-thiazoles and bis-1,3,4-thiadiazoles as anti-breast cancer agents. J. Chem. Res. 2016, 40, 120-125. [CrossRef]

33. Gomha, S.M.; Kheder, N.A.; Abdelhamid, A.O.; Mabkhot, Y.N. One pot single step synthesis and biological evaluation of some novel bis(1,3,4-thiadiazole) derivatives as potential cytotoxic agents. Molecules 2016, 21, 1532. [CrossRef]

34. Gomha, S.M.; Riyadh, S.M.; Abbas, I.M.; Bauomi, M.A. Synthetic utility of ethylidenethio- semicarbazide: Synthesis and anti-cancer activity of 1,3-thiazines and thiazoles with imidazole moiety. Heterocycles 2013, 87, 341-356.

35. Gomha, S.M.; Abdel-Aziz, H.M. Synthesis and antitumor activity of 1,3,4-thiadiazole derivatives bearing coumarine ring. Heterocycles 2015, 91, 583-592. [CrossRef]

36. Abbas, I.M.; Gomha, S.M.; Elaasser, M.M.; Bauomi, M.A. Synthesis and biological evaluation of new pyridines containing imidazole moiety as antimicrobial and anticancer agents. Turk. J. Chem. 2015, 39, 334-346. [CrossRef]

37. Gomha, S.M.; Salah, T.A.; Abdelhamid, A.O. Synthesis, characterization and pharmacological evaluation of some novel thiadiazoles and thiazoles incorporating pyrazole moiety as potent anticancer agents. Monatsh. Chem. 2015, 146, 149-158. [CrossRef]

38. Gomha, S.M.; Khalil, K.D. A convenient ultrasound-promoted synthesis and cytotoxic activity of some new thiazole derivatives bearing a coumarin nucleus. Molecules 2012, 17, 9335-9347. [CrossRef]

39. Gomha, S.M.; Riyadh, S.M.; Mahmmoud, E.A.; Elaasser, M.M. Synthesis and anticancer activity of arylazothiazoles and 1,3,4thiadiazoles using chitosan-grafted-poly(4-vinylpyridine) as a novel copolymer basic catalyst. Chem. Heterocycl. Compd. 2015, 51, 1030-1038. [CrossRef]

40. Edrees, M.M.; Abu-Melha, S.; Saad, A.M.; Kheder, N.A.; Gomha, S.M.; Muhammad, Z.A. Eco-friendly synthesis, characterization and biological evaluation of some new pyrazolines containing thiazole moiety as potential anticancer and antimicrobial agents. Molecules 2018, 23, 1970. [CrossRef]

41. Gomha, S.M.; Abdalla, M.A.; Abdelaziz, M.; Serag, N. Eco-friendly one-pot synthesis and antiviral evaluation of pyrazolyl chalcones and pyrazolines of medicinal interest. Turk. J. Chem. 2016, 40, 484-498. [CrossRef]

42. Gomha, S.M.; Farghaly, T.A.; Mabkhot, Y.N.; Zayed, M.E.M.; Mohamed, A.M.G. Microwave-assisted synthesis of some novel azoles and azolopyrimidines as antimicrobial agents. Molecules 2017, 22, 346. [CrossRef] [PubMed]

43. El-Hashash, M.A.; Gomha, S.M.; El-Arab, E.E. Utility of pyrazolylchalcone synthon to synthesize azolopyrimidines under grindstone technology. Chem. Pharm. Bull. 2017, 65, 90-96. [CrossRef] [PubMed]

44. Naock, A.; Schroder, A.; Hartmann, H. Synthesis and spectral characterisation of a series of new heterocyclic triphenylmethane analogues. Dye Pigment. 2002, 57, 131-147. [CrossRef]

45. Gomha, S.M.; Farghaly, T.A.; Sayed, A.R. Design, Synthesis, and characterization of bis-thiazoles based on bis-hydrazonoyl chlorides. J. Heterocycl. Chem. 2017, 54, 1537-1542. [CrossRef]

46. Sravanthi, T.V.; Pottem, M.R.; Manju, S.L. Design and Synthesis of Bis-Thiazol-2-ylidenes. Asian J. Chem. 2013, $25,5370-5372$. [CrossRef]

47. Gomha, S.M.; Abdelrazek, F.M.; Abdelrahman, A.H.; Metz, P. Synthesis of some novel thiazole, thiadiazole and 1,4-phenylene-bisthiazole derivatives. Heterocycles 2016, 92, 954-967. [CrossRef]

48. Cutfield, S.M.; Dodson, E.J.; Anderson, B.F.; Moody, P.C.E.; Marshall, C.J.; Sulliva, P.A.; Cutfield, J.F. The crystal structure of a major secreted aspartic proteinase from Candida albicans in complexes with two inhibitors. Structure 1995, 3, 1261-1271. [CrossRef]

49. Priyadarshi, A.; Kim, E.E.; Hwang, K.Y. Structural insights into Staphylococcus aureus enoyl-ACP reductase (FabI), in complex with NADP and triclosan. Proteins Struct. Funct. Bioinform. 2010, 78, 480-486. [CrossRef]

50. Abbas, I.M.; Riyadh, S.M.; Abdallah, M.A.; Gomha, S.M. A novel route to tetracyclic fused tetrazines and thiadiazines. J. Heterocycl. Chem. 2006, 43, 935-942. [CrossRef]

51. Gomha, S.M.; El-Gendy, M.S.; Muhammad, Z.A.; Abdelhamid, A.O.; Abdel-Aziz, M.M. Utility of bis-hydrazonoyl chlorides as precursors for synthesis of new functionalized bis-thiadiazoles as potent antimicrobial agents. J. Heterocycl. Chem. 2018, 55, 844-851. [CrossRef]

52. Tunney, M.M.; Ramage, G.; Field, T.R.; Moriarty, T.F.; Storey, D.G. Rapid Colorimetric Assay for Antimicrobial Susceptibility Testing of Pseudomonas aeruginosa. Antimicrob. Agents Chemother. 2004, 48, 1879-1881. [CrossRef] [PubMed]

53. Available online: https://gaussian.com/citation/ (accessed on 6 July 2021).

54. Available online: http:/ / www.chemcomp.com (accessed on 6 July 2021). 